\title{
IMPACT OF AGRICULTURAL MACHINERY ON INCREASING EFFICIENCY OF NITROGEN FERTILIZERS USED IN TOP-DRESSING OF WINTER WHEAT GROWN WITH NO-TILL TECHNOLOGY
}

\author{
Evgeny Golosnoy, Maxim Sigida, Alexander Esaulko, Sergey Korostylev, Yuliya Grechishkina \\ Stavropol State Agrarian University, Russia \\ golosnoi@mail.ru, sigida@list.ru, aesaulko@yandex.ru, korostylev16@mail.ru,.nwg@mail.ru
}

\begin{abstract}
Scientific studies of nitrogen agrochemistry should be aimed at finding new ways for the most rational use of nitrogen fertilizers, ensuring a reduction in its unproductive losses and an increase in payback by yield increase. One of the factors affecting the efficiency of technical nitrogen use is forms of nitrogen-containing fertilizers. The importance of nitrogen top-dressings in the production of winter crops in modern conditions has increased due to the fact that over the past 15 years arable land saturation with organic fertilizers has decreased significantly, and the stocks of available nitrogen compounds in soils are often negligible. The search for methods to increase the efficiency of using nitrogen fertilizers under conditions of a significant decrease in their production and use necessitates a more detailed study of issues related to plant nutrition, their absorption of nutrients from the soil and applied fertilizers. The article reflects the results of studies on the effectiveness of various forms of nitrogen fertilizers used in different ways to fertilize winter wheat with no-till technology. As a result of the research for the 2015-2018 agricultural years, it was found that the highest productivity of the crop was obtained using the in-soil application of liquid nitrogen fertilizers, which exceeded the figures for the use of agricultural tools for surface application of the AMAZONE ZF-M 1500 spreader and AMAZONE UX 4200 Super sprayer, solid and liquid forms of nitrogen fertilizers.
\end{abstract}

Keywords: introduction methods, winter wheat yield, grain quality, nitrogen fertilizers, feeding.

\section{Introduction}

According to the UN estimates, with the current growth rate the earth's population may exceed 8 billion people by 2025. To solve the food problem in the first quarter of the XXI century, it is necessary to double the gross harvest, or to grow about 4 billion tons of grain. This can be achieved only on the basis of intensification of crop farming [1].

To meet the needs of the Russian population in agricultural products and expanded soil fertility reproduction, it is required to make about 16.5 million tons of mineral fertilizers annually, according to the far from optimal forecasts [2].

The analysis of the experimental data of the comparative assessment of different systems of crop farming in many countries of the world allows to make a conclusion that achievements in crop production are possible not due to the development of alternative forms of plant cultivation, but due to the improvement of the existing ones. This requires the development and implementation of optimal (resource - and energy-saving) zonal fertilizer systems in typical crop rotations, ensuring the preservation and expanded reproduction of soil fertility, achieving a sustainable increase in yield, improving product quality, increasing crop rotation productivity and increasing the economic efficiency [3;4].

To achieve optimal performance in increasing the yield and quality of farm crops, it is necessary to select the timing, techniques and methods of fertilizer introduction. It is essential to create conditions for maximum availability of nutrients for plants, to provide plants with optimal nutrition during the growing season, in particular during critical periods, that is, during the periods of the greatest need for fertilizers; to reduce losses of nutrients from leaching [5;6].

Methods and technologies of fertilizer introduction should ensure the placement of fertilizers in the zone of root system development and their minimal fixation by soil. Fertilizers should be introduced into a stable moist soil layer to ensure their good availability during the growing season. It should also be taken into consideration that nutrients can be washed out and shift as a result of diffusion. Mainly nitrogen fertilizers in the form of nitrates are washed out. This process usually takes place in early spring and late autumn, so it is important to choose the right time and method of nitrogen fertilizer introduction in order to bring it closer to the period of intensive nitrogen assimilation by plants [7-9].

No-till technology helps stop degradation and preserves soil fertility, increases material resources saving, as well as profitability of production. It is necessary to keep up to date and pay attention not 
only to the technologies of soil cultivation, but also to the in-depth study of effective methods of fertilizer introduction by various devices [10].

\section{Materials and methods}

The research was carried out from 2015 to 2017. Field experiments were conducted in the Central part of the Stavropol region, characterized by arid climatic conditions. The average annual precipitation was $506 \mathrm{~mm}$, the average annual air temperature was $10.7^{\circ} \mathrm{C}$. The soil cover of land use is mainly represented by southern black soil, which is currently characterized by an average content of humus (3.4-3.9\%), mobile phosphorus (18-21 mg. $\mathrm{kg}^{-1}$ ) and increased content of exchange potassium $\left(319-350 \mathrm{mg} \cdot \mathrm{kg}^{-1}\right)$. The reaction of the soil solution in the upper horizons of the soil is alkaline in the range of 7.6 to 8.0 .

The objective of the research was to study the effect of methods of nitrogen fertilizer introduction in early spring fertilizing on the yield of winter wheat, cultivated on no-till technology, on the southern black soil in the arid climatic zone.

The object of the research - variety of winter wheat "Grom".

The subject of the research were application methods of nitrogen fertilizers in feeding by means of different devices, presented in Table 1 .

Table 1

Scheme of experience

\begin{tabular}{|c|c|}
\hline Variant & Device \\
\hline Ammophos $\mathrm{N}_{12} \mathrm{P}_{52}-$ background (control) & - \\
\hline $\begin{array}{c}\text { background }+ \text { Ammonium nitrate Naa } 87 \\
\text { (common technology) }\end{array}$ & $\begin{array}{c}\text { mineral fertilizer spreader } \\
\text { AMAZONE ZF-M 1500 }\end{array}$ \\
\hline background + CAM87 kg / ha & sprinkler \\
\hline background + CAM 87 kg / ha & AMAZONE UX 4200 Super \\
\hline background + CAM 87 kg / ha & Duport liquilazer \\
\hline
\end{tabular}

\section{Results and discussion}

In the experiment the influence of methods of nitrogen fertilizer introduction to feeding on the yield of winter wheat cultivated on no-till technology in the Stavropol region was studied.

Weather conditions in 2014-2015 and 2015-2016 were unfavorable for the formation of the crop. Uneven distribution of precipitation in spring and summer had an adverse effect on the formation of the winter wheat crop. In general, $440 \mathrm{~mm}$ of precipitation fell in 2014-2015, which was lower than the average annual indicators by $13 \%$. The increased temperature regime was observed throughout the growing season of the crops, the average annual temperature exceeded the long-term indicators by $0.2^{\circ} \mathrm{C}$ in $2015-2016,449 \mathrm{~mm}$ of precipitation fell, the average annual temperature reached $10{ }^{\circ} \mathrm{C}$.

The most favorable agro-meteorological conditions for winter wheat yield formation were in 2016-2017. The amount of precipitation during the growing season of the crops $(511 \mathrm{~mm})$ exceeded the norm by $18 \%$, however, their distribution is contributed to the optimal moisture of crops and the formation of the highest yield of winter wheat. The average annual air temperature corresponded to the mean annual values of $10.7^{\circ} \mathrm{C}$.

Invariant 2 Ammonium nitrate was introduced by means of the mineral fertilizer spreader AMAZONE (Figure 1). Carbamide-ammonia mixture (CAM) in a dose of $87 \mathrm{~kg}$ of active substance of nitrogen; in variant 3 it was introduced by means of a trailed sprayer (Figure 2); in variant 4 - by means of a multi-injector (Figure 3); in variant 5 - by means of the Duport liquiliser (Figure 4).

The applied fertilizers, their doses and methods of their introduction in the experiment had a positive impact on the yield of winter wheat and quality indicators of the crop. Nitrogen fertilizers increased the crop yield relative to control by $1.86-2.66 \mathrm{t} \cdot \mathrm{ha}^{-1}$ and formed the grain of the fourth grade. In the control variant, the yield of winter wheat was almost two times lower in the formation of fodder grain. 
As a result, on the variant without the use of nitrogen fertilizers in winter wheat feeding the lowest yield in the experiment was formed $-2.68 \mathrm{t} \cdot \mathrm{ha}^{-1}$ with quality indicators corresponding to the grain of the fifth grade (Table 2).

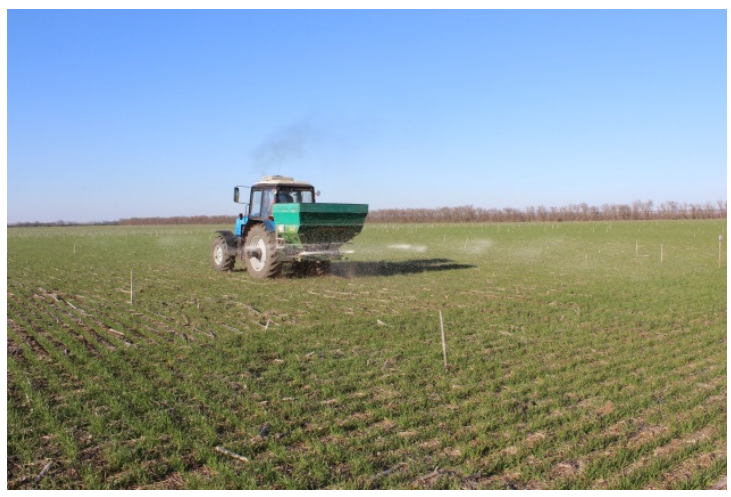

Fig. 1. Ammonium nitrate introduction by means ofmineral fertilizer spreaderAMAZONE ZF-M 1500

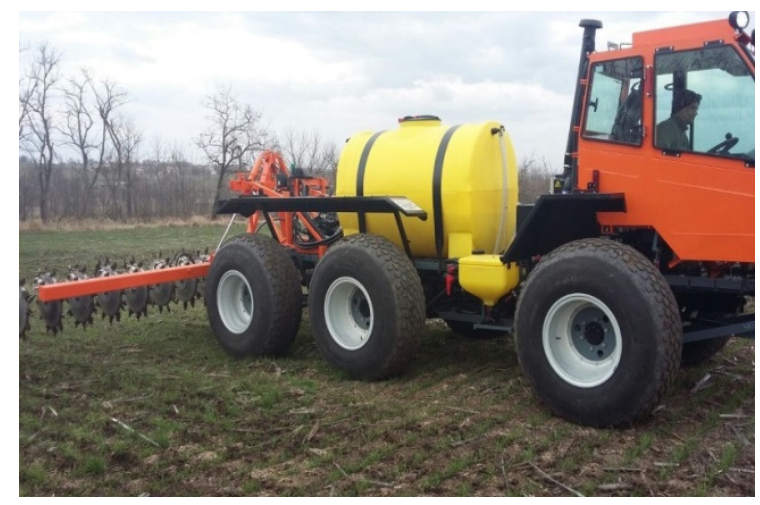

Fig. 3.Liquid nitrogen fertilizers introduction by means of multi-injector Tuman-2

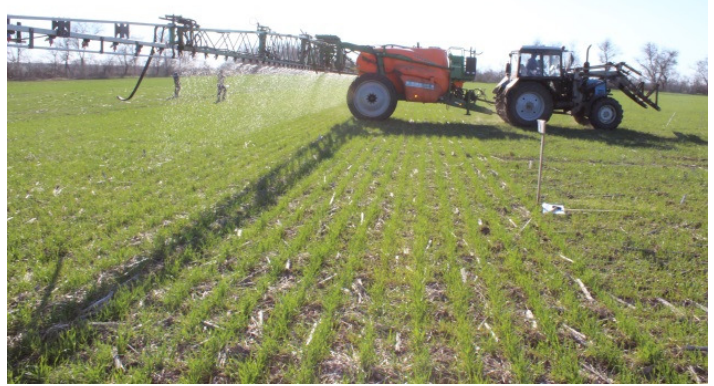

Fig. 2. Liquid nitrogen fertilizers introduction by means oftrailed sprayerAMAZONE UX 4200 Super

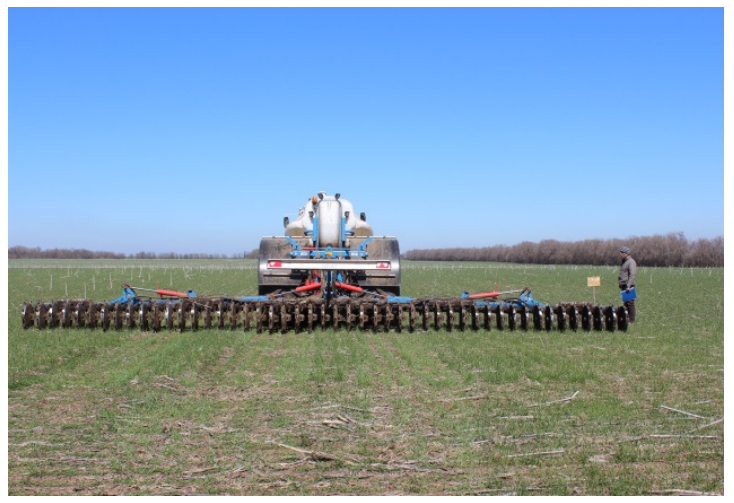

Fig. 4. Liquid nitrogen fertilizers introduction by means of Duport liquiliser

Table 2

Winter wheat quality and yield depending on the methods of nitrogen fertilizer introduction to feeding (average for 2015-2017)

\begin{tabular}{|c|c|c|c|c|c|}
\hline Name & Variant1 & Variant 2 & Variant 3 & Variant 4 & Variant 5 \\
\hline Feeding: 1-st & Control & $\begin{array}{c}\text { Naa } \\
(87 \text { active } \\
\text { substance) } \\
\text { mineral fertilizer } \\
\text { spreader } \\
\text { AMAZONE ZF-M } \\
1500\end{array}$ & $\begin{array}{c}\text { CAM } \\
\text { (87 active } \\
\text { substance) } \\
\text { sprinkler } \\
\text { AMAZONE UX } \\
4200 \text { Super }\end{array}$ & $\begin{array}{c}\text { CAM } \\
\text { (87 active } \\
\text { substance) } \\
\text { multi-injector } \\
\text { Tuman-2 }\end{array}$ & $\begin{array}{c}\text { CAM } \\
\text { (87 active } \\
\text { substance) } \\
\text { Duport } \\
\text { Liquiliser }\end{array}$ \\
\hline Protein & 9.1 & 10.8 & 11.0 & 11.2 & 12.6 \\
\hline Nature & 749 & 824 & 825 & 815 & 830 \\
\hline $\begin{array}{c}\text { Weightof 1000 } \\
\text { grains, tonns }\end{array}$ & 35.9 & 41.7 & 42.8 & 41.8 & 41.9 \\
\hline Glutenamount, \% & 15.2 & 18.1 & 18.3 & 18.9 & 23.8 \\
\hline $\begin{array}{c}\text { Gluten deformation } \\
\text { index }\end{array}$ & 90.6 & 56 & 80 & 53.0 & 60.3 \\
\hline Group & 2 & 1 & 1 & 1 & 1 \\
\hline Grade & 5 & 4 & 4 & 4 & 4 \\
\hline Yield, t $\cdot$ ha ${ }^{-1}$ & 2.68 & 4.54 & 5.16 & 5.34 & 5.30 \\
\hline
\end{tabular}


Table 3 shows that all nitrogen fertilizers studied in the experiment increased the main indicators of the economic efficiency compared to the control variant due to higher yield and quality of winter wheat. Fertilizer introduction reduced the cost price of 1 ton of grain from 22 to 30 Euro, compared to the control variant and increased the profit on 175-254 Euro and the level of profitability by 48.4$67.6 \%$.

The maximum economic efficiency indicators among all variants were obtained on the variant with the use of CAM at a dose of $87 \mathrm{~kg}$ of active substance of nitrogen by means of a multi-injector, which gave the greatest economic efficiency and the level of profitability was $73.5 \%$.

Table 3

\section{Economic efficiency assessment of nitrogen fertilizer introduction methods in winter wheat feeding}

\begin{tabular}{|c|c|c|c|c|c|c|}
\hline Item & Unit & $\begin{array}{l}\text { Variant } 1 \\
\text { (control) } \\
\end{array}$ & Variant 2 & Variant 3 & Variant 4 & Variant 5 \\
\hline Basicfertilizer & $\mathrm{kg}$ & \multicolumn{5}{|c|}{ Not introduced } \\
\hline Presowingfertilizer & $\mathrm{kg}$ & \multicolumn{5}{|c|}{$100 \mathrm{~kg} \cdot /$ ha Ammophos (MAP-N12P52) } \\
\hline Feeding & $\mathrm{kg}$ & - & $\begin{array}{c}\text { Naa } \\
\text { (87 active } \\
\text { substance) } \\
\text { mineral fertilizer } \\
\text { spreaderAMAZO } \\
\text { NE ZF-M } 1500\end{array}$ & $\begin{array}{c}\text { CAM } \\
\text { (87 active } \\
\text { substance) } \\
\text { sprinkler } \\
\text { AMAZONE } \\
\text { UX 4200 Super }\end{array}$ & $\begin{array}{c}\text { CAM } \\
\text { (87 active } \\
\text { substance) } \\
\text { multi- } \\
\text { injector } \\
\text { Tuman-2 }\end{array}$ & $\begin{array}{c}\text { CAM } \\
\text { (87 active } \\
\text { substance } \\
\text { ) } \\
\text { Duport } \\
\text { liquiliser }\end{array}$ \\
\hline Totalcostsfor 1 ha & EUR $\cdot$ ha $^{-1}$ & 266 & 352 & 365 & 368 & 367 \\
\hline Wagesandtaxes & EUR $\cdot$ ha $^{-1}$ & 46 & 77 & 88 & 91 & 90 \\
\hline Seeds & EUR $\cdot$ ha $^{-1}$ & 26 & 26 & 26 & 26 & 26 \\
\hline Plantprotectionagents & EUR $\cdot$ ha $^{-1}$ & 21 & 21 & 21 & 21 & 21 \\
\hline Rentpayment & EUR $\cdot$ ha $^{-1}$ & 57 & 57 & 57 & 57 & 57 \\
\hline Bankinterest & EUR $\cdot$ ha $^{-1}$ & 28 & 28 & 28 & 28 & 28 \\
\hline Others & EUR $\cdot$ ha $^{-1}$ & 12 & 15 & 15 & 15 & 15 \\
\hline $\begin{array}{l}\text { Mineral fertilizers in } \\
\text { total, including }\end{array}$ & $\mathrm{EUR} \cdot \mathrm{ha}^{-1}$ & 36 & 86 & 89 & 89 & 89 \\
\hline whensowing & $\mathrm{EUR}^{\mathrm{h}} \mathrm{ha}^{-1}$ & 36 & 36 & 36 & 36 & 36 \\
\hline Firstfeeding. & EUR $\cdot \mathrm{ha}^{-1}$ & - & 50 & 53 & 53 & 53 \\
\hline Fuelsandlubricants & EUR $\cdot$ ha $^{-1}$ & 11 & 11 & 11 & 11 & 11 \\
\hline Depreciation & EUR $\cdot$ ha $^{-1}$ & 29 & 29 & 29 & 29 & 29 \\
\hline Yield & $\mathrm{t} \cdot \mathrm{ha}^{-1}$ & 2.68 & 4.54 & 5.16 & 5.34 & 5.30 \\
\hline Costprice & $\mathrm{EUR} \cdot \mathrm{t}^{-1}$ & 99 & 77 & 71 & 69 & 69 \\
\hline Productprice & $\mathrm{EUR} \cdot \mathrm{t}^{-1}$ & 105 & 119 & 119 & 119 & 119 \\
\hline Revenue & $\mathrm{EUR} \cdot \mathrm{t}^{-1}$ & 282 & 542 & 616 & 638 & 633 \\
\hline Profit & $\mathrm{EUR} \cdot \mathrm{t}^{-1}$ & 16 & 191 & 252 & 270 & 266 \\
\hline Efficiency & $\%$ & 5.9 & 54.3 & 69.1 & 73.5 & 72.5 \\
\hline
\end{tabular}

\section{Conclusions}

All doses of nitrogen fertilizers had a positive impact on the yield and structural parameters of winter wheat. Nitrogen fertilizers in a dose of $87 \mathrm{~kg}$, introduced in various ways, increased the protein parameters by $1.7-3.5 \%$, nature by 66-81 units, weight of 1000 grains by 5.8-6.9 g, the amount of gluten by 2.9-7.6\%, and the gluten deformation index corresponded to 1 good group. The highest crop yield was obtained by mean of multi-injector Tuman-2 and Duport liquiliser $5.3-5.34 \mathrm{t} \cdot \mathrm{ha}^{-1}$, which exceeded the indicators of nitrogen fertilizer introduction by means of the mineral fertilizer spreaderAMAZONE ZF-1500 M and sprinklerAMAZONE UX 4200 Super of 0.8-0.18 $\mathrm{t} \cdot \mathrm{ha}^{-1}$.

The maximum economic efficiency indicators among all variants were obtained in the variant with the use of CAM at a dose of $87 \mathrm{~kg}$ of active substance of nitrogen by means of the multi-injector, which gave the greatest economic efficiency-the level of profitability was $73.5 \%$. 


\section{References}

[1] Esaulko A.N., Salenko E.A., Sigida M.S., Korostylev S.A., Golosnoy E.V. Agrochemical Principles of Targetting Winter Wheat Yield on Leached Chernozem of the Stavropol Elevation. Biosciences Biotehnology Research Asia, T.12. No. 1, 2015. pp. 301-309.

[2] Esaulko A. N., Ozheredova A. Yu., Sigida M.S., Voskoboinikov A.V., Podkolzin O.A. Introduction of Calculated Doses of Mineral Fertilizers to Achieve Maximum Productivity of Winter Wheat Varieties on Chernozem Leached Stavropol Upland. Research journal of pharmaceutical biological and chemical sciences, T. 8. B. 6, 2017. pp. 778-781.

[3] Tskhovrebov V.S., Faizova V.I., Mar' in A.N., Novikov A.A., Nikiforova A.M. Changing in ammonifiers of virgin land and black-earth ploughland to Central Ciscaucasia. Research Journal of Pharmaceutical, Biological and Chemical Sciences, 7 (4), 2016. pp. 2174-2177.

[4] Vlasova O.I., Perederieva V.M., Volters I.A., Tivikov A.I., Trubacheva L.V. Change in microbiological activity under the effect of biological factors of soil fertility in the central forecaucasuschernozems. Biology and Medicine. No. 7 (5), 2015. BM-146-15.

[5] Tshovrebov V.S., Faizova V.I., Kalugin D.V., Nikiforova A.M., Lysenko V.Y. Document Changes in the content of organic matter in black soils of Central Ciscaucasia caused by their agricultural use. Biosciences Biotechnology Research Asia, 13 (1), 2016. pp. 231-236.

[6] Tskhovrebov V.S., Faizova V.I., Mar'in A.N., Kalugin D.V., Novikov A.A. Document Changing population by aerobic nitrogen-fixing bacteria in natural and anthropogenically transformed chernozemsbiogeocenoses Central Ciscaucasia. Source of the Document Research Journal of Pharmaceutical, Biological and Chemical Sciences, 7 (4), 2016. pp. 2178-2182.

[7] Sun M., Huo Z., Zheng Y., Feng S., Mao X. Quantifying long-term responses of crop yield and nitrate leaching in an intensive farmland using agro-eco-environmental model. Science of the Total Environment, 2018. pp. 1003-1012.

[8] Nouwakpo S.K., Song J., Gonzalez J.M. Soil structural stability assessment with the fluidized bed, aggregate stability, and rainfall simulation on long-term tillage and crop rotation systems. Soil and Tillage Research 178, 2018. pp. 65-71.

[9] Sarker J.R., Singh B.P., Cowie A.L., Badgery W., Dalal R.C. Agricultural management practices impacted carbon and nutrient concentrations in soil aggregates, with minimal influence on aggregate stability and total carbon and nutrient stocks in contrasting soils. Soil and Tillage Research 178, 2018. pp. 209-223.

[10] Hou R., Xu X., Ouyang Z. Effect of experimental warming on nitrogen uptake by winter wheat under conventional tillage versus no-till systems. Soil and Tillage Research, 2018. pp. 116-125. 